\title{
Investigation of the comfort properties of traditional woven fabrics with different structural parameters
}

DOI: 10.35530/IT.071.04.1701

\section{ABSTRACT - REZUMAT}

\section{Investigation of the comfort properties of traditional woven fabrics with different structural parameters}

Turkish traditional Buldan weavings are known as special fabrics in terms of providing comfortable clothes which are known to be natural and healthy in Denizli, Turkey. The research presented in this paper assesses the effects of different fabric structural parameters of Buldan fabrics on comfort properties such as thermal resistance, thermal absorptivity, water vapour permeability and air permeability. Five different Buldan fabrics woven with different fabric structural parameters were produced. According to test results, cotton/Tencel Buldan fabrics indicated similar comfort properties with the $100 \%$ cotton Buldan fabric properties. Additionally, the lowest thermal absorptivity was observed from $100 \%$ cotton Buldan fabrics which give the warmth feeling among the evaluated samples.

Keywords: Buldan woven fabric, fabric structural parameters, thermal resistance, water vapour permeability, air permeability.

\section{Investigarea proprietăților de confort ale țesăturilor tradiționale cu diferiți parametri structurali}

Țesăturile tradiționale turcești Buldan sunt cunoscute ca țesături speciale din punctul de vedere al confortului îmbrăcămintei și al originii naturale în Denizli, Turcia. Cercetările prezentate în această lucrare evaluează influența diferiților parametri structurali ai țesăturilor Buldan asupra proprietăților de confort, precum rezistența termică, absorbția termică, permeabilitatea la vapori de apă și permeabilitatea la aer. Au fost produse cinci țesături Buldan cu diferiți parametri structurali. Conform rezultatelor testelor, țesăturile Buldan din bumbac/Tencel au indicat proprietăți de confort similare cu cele ale țesăturilor Buldan din 100\% bumbac. În plus, cea mai mică absorbție termică a fost observată la țesăturile Buldan din 100\% bumbac, care dau senzația de căldură.

Cuvinte-cheie: țesătură Buldan, parametri structurali ai țesăturii, rezistență termică, permeabilitate la vapori de apă, permeabilitate la aer

\section{INTRODUCTION}

Buldan which is a town of Denizli in Turkey is the weaving center for unique Buldan fabric. The weaving history of Buldan is very old. Today, textile sector has become a way of life in Buldan with workshops and factories as the small industries have developed [1]. Traditional Buldan weavings are known as special fabrics in terms of providing comfortable clothes which are known to be natural and healthy. Buldan fabric is generally known to be produced from natural fibers such as cotton, wool, linen and silk in the historical sources. And it is also known with its traditional name as "Buldan twisted clothes" owing to fabric structure with high twisted yarns. Buldan fabric is a plain weave which is the basic and most durable weave type. Although high twisted yarns are generally preferred as weft yarns, high twisted warp yarns may be also preferred in the fabric construction. The fabric gains its high wrinkle feature with the hot soap washing process. Since the wrinkled fabric width decreases with respect to high yarn twist level, those fabrics do not contact the human body which results with thermal insulation owing to air gaps. At the same time, since the Buldan fabrics are woven with high twisted yarns, they provide ease of movement owing to their flexibility as well as cooling effect owing to the air gaps in the curly surface. High sweat absorption of Buldan fabrics made of cotton is also another attractive advantage for the consumers demanding for healthy products [2-6]. It has been also observed that Buldan fabrics have been utilized for apparel sectors where they have been preferred for woman's blouses especially [3, 6]. As the Buldan fabrics have been produced in a traditional way, the productions with semi and full automatic weaving machines have been in progress with the developing technology [7]. It was mentioned in the literature that today's Buldan weavings have lower yarn twists when compared to older Buldan fabrics. Also it is supported that early Buldan fabric structures were much crimped and had higher fineness comparing to todays' Buldan fabrics sold in the market. Today most of the Buldan fabrics have been woven in the industrial factories blending with synthetic yarns. When the warp yarns are selected with low yarn twist level and the weft yarns are selected 
with high twist level or vice versa, this fabric quality is called as $50 \%$ twisted Buldan cloth. Today there are fewer accessible $100 \%$ twisted Buldan clothes produced on hand looms [8-9].

Buldan fabrics are highly preferred especially for summer clothes owing to their soft and comfortable feeling. Thermal comfort properties for any textile products can be listed as thermal conductivity, thermal resistance, thermal absorptivity, water vapour permeability, air permeability and moisture transport. The permeability of the fabrics depends on the raw material (such as fiber type, fineness and cross section etc.), yarn properties (such as linear density, twist level, yarn hairiness, etc.), and fabric structural properties (such as geometrical properties, weave type, fabric thickness, porosity etc.) as well as the finishing processes applied to those fabrics. For an acceptable thermal comfort of an ideal fabric structure: i) a fabric should reveal high thermal resistance for cold protection, ii) a fabric should indicate low water vapour resistance for an effective heat transfer for warm climate conditions, iii) a fabric should reveal high moisture transfer characteristics [10-11].

Thermal conductivity of any fabric has a strong relationship with the air trapped in the fabric and the thermal conductivity coefficient of the fibers made of them. Since the thermal conductivity coefficient of the air is low, fabrics having higher amount of air have also low thermal conductivity coefficient [12]. As the material thickness and the air trapped inside it increase, it is observed that the materials' thermal resistance and water vapour resistance also increase while its air permeability decreases. There should be a high ratio of air in a textile material which has high thermal insulation. This is because of the lower thermal conductivity coefficient of the air compared to textile materials. Stagnant air is an ideal insulating material. When the fibers' thermal conductivity coefficients (Watt/meter-Kelvin) are considered, coefficient of thermal conductivity for cotton is 71 while this value is 25 for stagnant air [10-14]

In literature, it has been observed that factors such as the hydrophilic nature of the fiber forming the fabric structure, high thermal conductivity and high water vapour permeability ensure that the liquid can be delivered rapidly to the outer layers [15]. Thermal absorptivity and water vapour permeability properties are known to be increasing with the highly twisted yarns in the fabrics. It was also observed that the fabrics with high twisted yarns gave cool feeling owing to high thermal absorptivity. However thermal resistance decreased as the yarn twist increased [10].

As the linear density of yarns utilized in the fabric decreases, thermal resistance and thermal absorptivity values decrease while the water vapour permeability increases. Thermal resistance values increase as the fabric thickness increase whereas water vapour and air permeability properties decrease. When the fiber properties of cotton, viscose and Tencel were evaluated in terms of comfort properties in a research; Cotton fiber revealed higher thermal resistance and warmer feeling, Tencel fiber indicated higher water vapour permeability and viscose fiber indicated higher air permeability [16]. Thermal resistivity decreased with the increasing yarn twist while thermal absorptivity and water vapour permeability increased. It was also observed that fabrics with high twisted yarns gave cooler feelings owing to high thermal absorptivity features [17]. In another study it was also declared that there are many parameters related to fabric structure which influence water vapour permeability. Those parameters were followed as: i) fiber properties (type, count, composition, porosity, cross section), ii) yarn properties (linear density, yarn diameter, twist, hairiness, yarn geometry), iii) fabric properties (fabric porosity, thickness and warp/weft density) [12].

It was declared in the literature that fabric thickness and fiber type indicated high correlation with the water vapour transport ratio. However, the moisture transport did not indicate any relationships with those two factors. Most of the study emphasized that there was a high relationship between water vapour permeability and air permeability properties [12, 18]. Fabrics have a porosity structure owing to many fiber combinations. Water vapour transfer occurs among the fibers and yarns' space as well as within the fibers. Since diffusion coefficient of water vapour which transfers within the fibers is lower than the coefficient of water vapour which transfers through the air; Water vapour diffusion increases as the amount of present air increases. Diffusion coefficient of water vapour permeability through the air is $0.239 \mathrm{~cm}^{2} \cdot \mathrm{s}^{-1}$ while this value decreases to $10^{-7} \mathrm{~cm}^{2} \cdot \mathrm{s}^{-1}$ through the cotton fabric. Water vapour in the fabric is known to be spreading from the center to fabric surface and from the fiber inner surface to the fiber outer surface hence it evaporates from the fabric surface. This diffusion theorem does not work according to Fick law in the hydrophilic fibers which highly absorb the water molecules. Swelling of the fibers result with less air spaces hence the diffusion spread decrease $[12,19]$. Air permeability which facilitates easier thermal transport and determines the breathability properties of fabrics is an important parameter for comfort properties. Air permeability of the fabrics is influenced from the fabric porosity. Fabric porosity which affects the permeability properties of the fabric is the total space volume depending mainly on the fabric geometry, raw materials and yarn properties. Porosity between the fibers and fabrics depend on the structural factors such as fiber fineness, fiber cross section, weave type, yarn density and yarn twist. When the air flow in the porous structure is considered, the shape, layout and size distribution of the spaces are accepted as the important factors. It was also observed that there is a reverse proportion between the air permeability of the fabrics with their thickness [12].

Since fabric density determines the pores' size, it is an important parameter for air permeability. Fabric porosity decreases as the fabric density increases. 
When the air permeability of the fabric is associated with cover factor, it was observed that tight fabrics which have little pores with high cover factor prevent the air permeability [12]. Since the structural parameters of the fabrics such as its consisting yarns' twist, linear density, packing ratio influence the porosity between and within the yarn porosity, those parameters influence the total air permeability ratio. When the yarn twists in cotton fabrics were evaluated, it was concluded that porosity increased with the twist ratio. Yarn diameter was also considered as an important parameter since it determined fabric porosity and cover factor [12, 20].

In literature, there are not many studies considering the relationship between the unique fabric groups "Buldan fabric" and the fabrics' structural properties such as yarn composition, yarn twist, fabric weight, and fabric thickness in terms of thermal comfort properties. This study aims to contribute to literature by investigating the thermal resistivity $\left(\mathrm{m}^{2} \cdot \mathrm{KW}^{-1}\right)$, thermal absorptivity $\left(\mathrm{Wm}^{-2} \mathrm{~s}^{1 / 2} \mathrm{~K}^{-1}\right)$, relative water vapour permeability (\%) and air permeability $\left(\mathrm{l} / \mathrm{m}^{2} / \mathrm{s}\right)$ properties of Buldan fabrics produced with different fabric structural parameters. This study is thought to be useful in terms of thermal evaluations of local Buldan fabrics which will more likely to be encountered in apparel clothes.

\section{MATERIALS AND METHODS}

\section{Material}

In this study, plain woven traditional Buldan fabrics were produced on Sulzer projectile weaving loom. The effect of constructional parameters such as yarn count, fabric density, yarn twist, fabric thickness, and fabric unit weight were indicated as in table 1. Those parameters were thought to be influential factors on fabrics' thermal properties as well as on water vapour permeability and air permeability properties evaluated within the study. Microscopic images of original and 20 times magnified samples which were taken under a microscope (Mshot Digital Microscope Camera MS60) coupled to a digital camera were also revealed in figure 1.

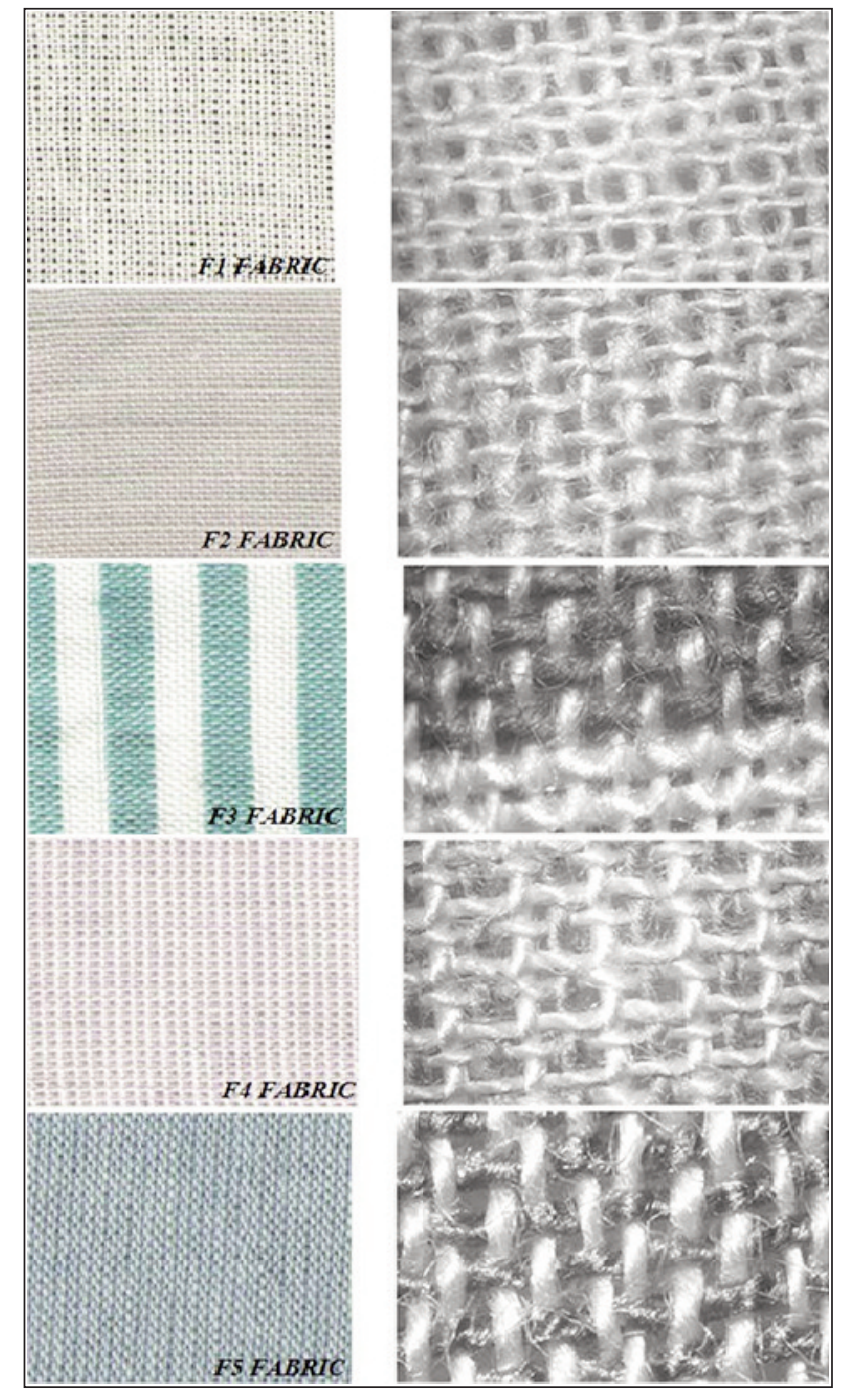

Fig. 1. Buldan fabrics' photograph and microscopic $(\times 20)$ images

\section{Methods}

In this study it was aimed to investigate the effect of fabric structural parameters on some comfort properties of Buldan fabrics. For this, Alambeta, Permetest and SDL Atlas M021A model Air Permeability Tester devices were used for the evaluation of thermal comfort, water vapour and air permeability properties

Table 1

\begin{tabular}{|c|c|c|c|c|c|c|c|c|c|}
\hline \multicolumn{10}{|c|}{ CONSTRUCTIONAL PARAMETERS OF BULDAN FABRICS } \\
\hline \multirow{2}{*}{$\begin{array}{l}\text { Fabric } \\
\text { code }\end{array}$} & \multirow{2}{*}{$\begin{array}{c}\text { Fabric } \\
\text { composition } \\
(\%)\end{array}$} & \multicolumn{2}{|c|}{$\begin{array}{c}\text { Yarn count } \\
(\mathrm{Ne})\end{array}$} & \multicolumn{2}{|c|}{$\begin{array}{c}\text { Fabric density } \\
\text { (thread/cm) }\end{array}$} & \multicolumn{2}{|c|}{$\begin{array}{c}\text { Yarn Twist } \\
(\mathrm{T} / \mathrm{m})\end{array}$} & \multirow{2}{*}{$\begin{array}{c}\text { Fabric } \\
\text { thickness } \\
(\mathrm{mm})\end{array}$} & \multirow{2}{*}{$\begin{array}{c}\text { Fabric unit } \\
\text { weight } \\
\left(\mathrm{g} / \mathrm{m}^{2}\right)\end{array}$} \\
\hline & & Warp & Weft & Warp & Weft & Warp & Weft & & \\
\hline $\mathrm{F} 1$ & $100 \%$ Cotton & $50 / 1$ Cotton & 30/1 Cotton & 26 & 24 & $971 \mathrm{Z}$ & $804.6 \mathrm{Z}$ & 0.27 & 86.9 \\
\hline $\mathrm{F} 2$ & $\begin{array}{c}30 \% \text { Cotton }- \\
70 \% \text { Tencel }\end{array}$ & $50 / 1$ Cotton & 20/1 Tencel & 28 & 22 & $899.8 \mathrm{Z}$ & $732.8 \mathrm{Z}$ & 0.33 & 102 \\
\hline $\mathrm{F} 3$ & $\begin{array}{c}30 \% \text { Cotton }- \\
70 \% \text { Tencel } \\
\end{array}$ & $50 / 1$ Cotton & 20/1 Tencel & 26 & 23 & $685.8 \mathrm{Z}$ & $667.2 \mathrm{Z}$ & 0.31 & 105 \\
\hline $\mathrm{F} 4$ & $\begin{array}{c}65 \% \text { Cotton - } \\
35 \% \text { Tencel } \\
\end{array}$ & 50/1 Cotton & $\begin{array}{c}20 / 1 \\
\text { Cotton/Tencel }\end{array}$ & 26 & 26 & $710 \mathrm{Z}$ & $675 \mathrm{Z}$ & 0.33 & 107.4 \\
\hline F5 & $\begin{array}{c}35 \% \text { Cotton - } \\
65 \% \text { Tencel }\end{array}$ & 30/1 Cotton & 20/1 Tencel & 26 & 21 & $1088.4 \mathrm{Z}$ & Core-Spun & 0.34 & 107.7 \\
\hline
\end{tabular}


respectively. Three repeats were conducted for each sample measurement. Fabric samples were conditioned at $65 \pm 2 \%$ relative humidity and $20 \pm 2^{\circ} \mathrm{C}$ for 24 hours in accordance with the ASTM D 1776-08 (2009) standards prior to all mentioned tests.

Thermal resistivity and thermal absorptivity

Thermal properties such as thermal resistance $(r)$ and thermal absorptivity $(b)$ of Buldan fabrics were measured by using Alambeta instrument. Average of three measured results was calculated as the means for determining the means. The definition of thermal properties mentioned in the study as; thermal resistance and thermal absorptivity are briefly summarized below.

Thermal resistance is a measure of the body's ability to prevent heat from flowing through it. Under a certain condition of climate, if the thermal resistance of clothing is small, the heat energy will gradually reduce with a sense of coolness [20]. Thermal resistance has a relationship with fabric thickness and thermal conductivity coefficient as indicated in equation (1) [21]:

$$
r=\frac{h}{\lambda}\left(\mathrm{m}^{2} \mathrm{~K} / \mathrm{W}\right)
$$

where $r$ is thermal resistance, $h$ - fabric thickness (m), $\lambda$ - thermal conductivity coefficient (W/mK).

Thermal absorptivity is the objective measurement of the warm-cool feeling of fabrics. This parameter allows assessment of the fabric's character in the aspect of its "cool-warm" feeling [22]. Thermal absorption is the heat flow when the two materials of different temperature contact each other. If a skin contacted fabric has lower temperature than the skin, heat flow from the skin to the fabric will result with a cool feeling. Low thermal absorption provides warmer feeling while high thermal absorption leads to cooler feeling. This parameter is important especially for the comfort property of the cloths at first dressing moments in cold winter days. The equation (2) displays the calculation of thermal absorptivity. As it is observed thermal absorptivity is directly proportional with materials' thermal conductivity, density and specific heat [22-24].

$$
b=(\lambda \rho c)^{1 / 2}\left(\mathrm{Ws}^{1 / 2} / \mathrm{m}^{2} \mathrm{~K}\right)
$$

where $\lambda$ is thermal conductivity $(\mathrm{W} / \mathrm{mK}), \rho-$ density $\left(\mathrm{kg} / \mathrm{m}^{3}\right), c-$ specific heat $(\mathrm{J} / \mathrm{kgK})$.

Relative water vapour permeability

Relative water vapour permeability is the fabric ability to transfer water vapour in percentage scale.

Especially for products which are used in hot weather or for active sports when perspiring is maximal, water vapour permeability is one of the most important comfort parameters. If the evaporative resistance of the samples is too high to transmit heat, the stored heat in the body cannot be dissipated and causes an uncomfortable sensation. Garments which have high water vapour permeability feature can easily ensure evaporation of moisture from body after sweating and enhances the sense of comfort [25-26]. Among this study, relative water vapour permeability was measured on 'Permetest' instrument working on similar skin model principle according to EN ISO 11092 test standard.

Air permeability test

Air permeability of the fabrics was measured based on EN ISO 9237 standard using a SDL Atlas Digital Air Permeability Tester Model M $021 \mathrm{~A}$ at $20 \pm 2^{\circ} \mathrm{C}$ and $65 \% \pm 4 \%$ humidity [27]. Measurements were performed by application under $100 \mathrm{~Pa}$ air pressure per $20 \mathrm{~cm}^{2}$ fabric surface.

Measurement of fabric thickness

Fabric thickness should be considered since it determines most of the physical properties of the fabrics. Buldan woven fabrics' thickness were measured according to ASTM D1777-96 (2007) by using R\&B J.H. Heal test equipment in order to observe the effects of different constructional parameters on fabric thickness.

\section{RESULTS AND DISCUSSION}

\section{Analysis of the thermal resistivity}

In figure 2, the thermal resistivity values of Buldan woven fabrics are presented. According to figure 2, fabric thickness and fabric weight are considerable factors on thermal resistivity of fabrics having different raw materials at different compositions. It was observed that fabrics having low fabric weight and fabric thickness revealed lower thermal resistivity ( $F 1$ and F3). Some researchers also declared in their studies that thermal resistance increases with the increase of material thickness and air entrapped in the fabric [28]. It can also be emphasized that fabric thickness was a considerable factor for thermal resistivity. This result might also be supported with the comparison of thermal resistivity results of $\mathrm{F} 1$ and F2 fabrics. F2 fabric indicated higher thermal resistivity which has lower fabric weight but higher fabric thickness value compared to F1 fabric.

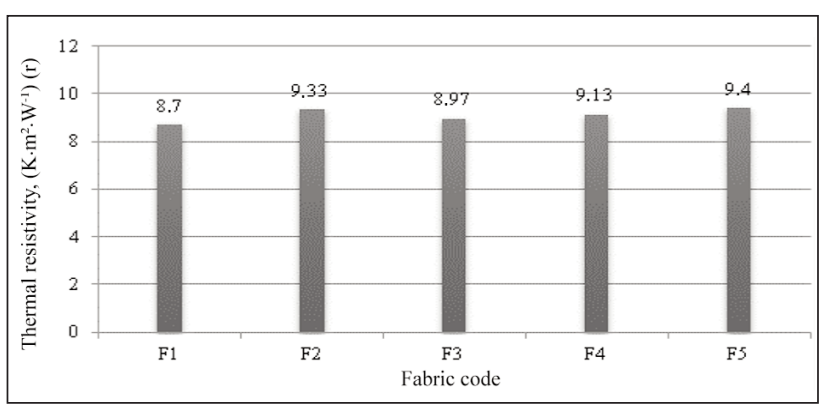

Fig. 2. Thermal resistivity values of fabrics

When the F2 and F3 fabrics which have the same fabric compositions were evaluated; it was observed that F3 fabric having high fabric weight and also with low fabric thickness indicated lower thermal resistivity than F2 fabric which has low fabric weight but high fabric thickness.

When the F4 and F5 fabrics having different cotton/ Tencel ratios with same fabric weight were evaluated, 
it was observed that they revealed similar thermal resistivity values. Additionally, among the low fabric weight groups as F1, F2 and F3; F1 fabric indicated lower thermal resistivity. This result might be attributed to reducing effect of high twisted weft and warp yarns in addition to low fabric weight of F1. As it is known, thermal resistivity decreases as the yarn twist increases. This result is supported with Ozdil et al. study where they concluded that thermal resistance values decreased with the yarn twist [17].

\section{Analysis of the thermal absorptivity}

Buldan woven fabrics are preferable owing to their cool feeling properties in summer times. Unique property of cotton fiber combined with high twisted yarns provide garments keeping the microclimate conditions constant owing to Buldan fabrics' crimped surface. The result of crimped fabric surface, garments with Buldan fabrics do not contact the skin directly. In figure 3, the thermal absorptivity values of Buldan woven fabrics are presented. According to figure 3, F1 and F2 fabrics indicating lower thermal absorptivity are expected to provide warmer feeling while F3, F4 and F5 fabrics which reveal higher thermal absorptivity values are expected to give cool feeling.

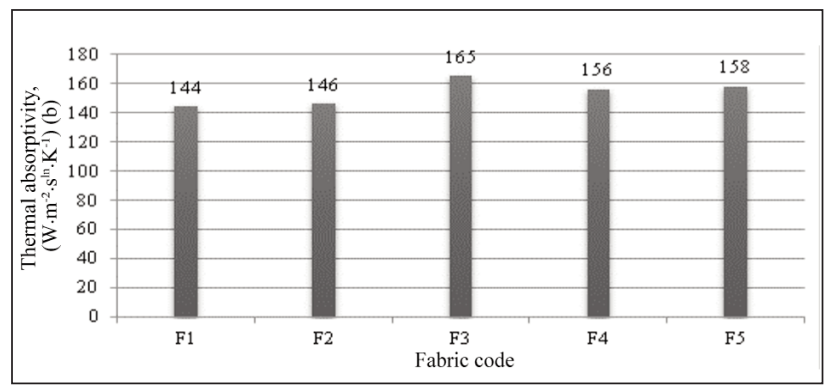

Fig. 3. Thermal absorptivity values of fabrics

When the F1 and F2 fabrics which indicate lower thermal absorptivity are considered, it is observed that those fabrics have low fabric weight. However, in the manner of fiber composition, $\mathrm{F} 1$ fabric made of $100 \%$ cotton and F2 fabric made of cotton/Tencel did not vary between each other in terms of thermal absorptivity results. Among five different Buldan woven fabrics, $100 \%$ cotton F1 fabric with low fabric weight and low thickness indicated the lowest thermal absorptivity with the warmth feeling.

F4 and F5 fabrics which have the same fabric weight and thickness but different fiber composition were evaluated, F4 fabric indicated slightly lower thermal absorptivity. This result might be attributed to higher cotton ratio of $\mathrm{F} 4$ fabric composition.

Among all fabric groups, F3 fabric indicated the highest thermal absorptivity with cool feeling. Considering the F3, F4 and F5 fabrics revealing the highest thermal absorptivity values, it was observed that F3 fabric indicated the highest value. This result may be attributed to higher Tencel composition in F3 fabric compared to F4 and F5 fabrics.
In the early literature, it was declared that thermal absorptivity increases as the yarn twist of the fabrics increased $[10,17]$. However, in this study related to Buldan fabrics, maximum thermal absorptivity was obtained from F3 fabrics which have the lowest yarn twist. Obtained results might be explained as follow; in figure 3, it was observed that highest thermal absorptivity (coolest feeling) was obtained from F3 fabric while lowest thermal absorptivity (warmth feeling) was found F1 fabric. On the other hand, when the air permeability values of these fabrics were evaluated, just opposite of this situation was encountered with where F3 fabric had the minimum air permeability and F1 fabric had the maximum air permeability (in figure 5). This result may require considering the evaluation of thermal absorptivity and air permeability properties together. Since the fabric with low air permeability (F3) has low amount of air trapped inside, it is thought that low amount of stagnant air in the fabric structure might result with cool feeling. Hence fabrics with low air permeability will result with cool feeling. Since air passing through the fabric provides the increment of the stagnant air in the fabrics' pores with high air permeability properties, thermal insulation of the fabric will increase with warmth feeling.

\section{Analysis of the water vapour permeability}

In figure 4, the water vapour permeability values are presented. Highest water vapour permeability belongs to $100 \%$ cotton $\mathrm{F} 1$ fabric with the lowest fabric weight and fabric thickness. F2, F3, F4 and F5 indicated similar water vapour permeability values. When the fabric constructional parameters are considered, fabric thickness was a considerable factor for water vapour permeability.

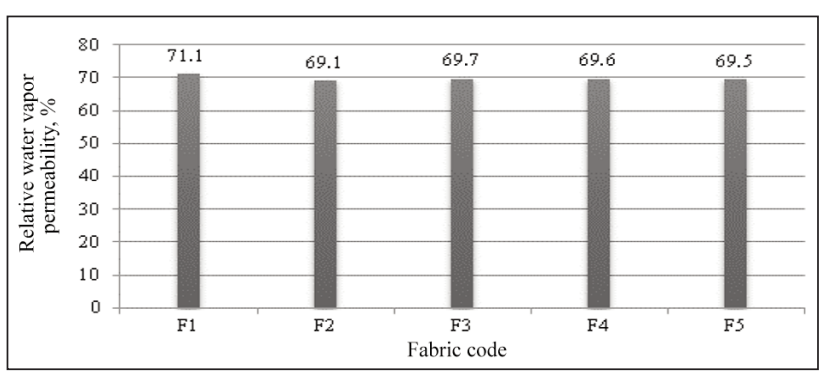

Fig. 4. Water vapour permeability values of fabrics

Although, F2, F3, F4 and F5 fabrics having the different fabric weight between each other (except for the fabrics of F4 and F5) but the fabric thickness values were similar to each other. Since those fabrics indicated similar water vapour permeability results, it may be concluded that fabric thickness factor was more dominant on water vapour permeability property. On the other hand, F4 and F5 fabrics having different fiber blend ratios of cotton/Tencel but having same fabric weight and fabric thickness revealed similar water vapour permeability which indicated that fiber blend ratio of cotton/Tencel fabrics was not a prominent factor on water vapour permeability values. 


\section{Analysis of the air permeability}

In figure 5, the air permeability values of fabrics are presented. According to figure 4, the highest air permeability was obtained from F1 fabric. When the constructional property of $\mathrm{F} 1$ fabric was evaluated, it was observed that F1 fabric had lowest fabric weight and fabric thickness. Additionally, yarns consisting F1 fabric had higher twist level compared to F2, F3 and F4 fabrics. When the microscopic images (figure 1) of Buldan fabrics were observed, it may be observed that $\mathrm{F} 1$ has a more porosity surface structure.

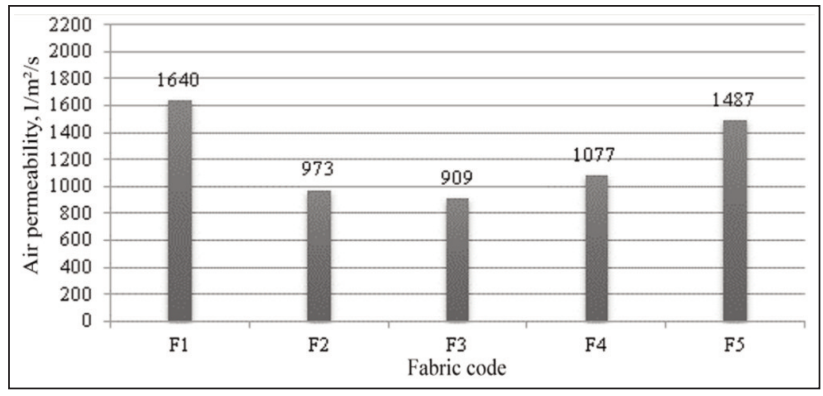

Fig. 5. Air permeability values of fabrics

On the other hand, the reason for F5 fabric permitting high air permeability despite its high fabric weight and fabric thickness may be attributed to its high twisted warp yarns. As it is known, as the yarn twist level increases, the surface porosity of the fabric will increase resulting with high air permeability. According to figure 5 , the lowest air permeability value was obtained from F3 fabric where F2 followed it. This result may be explained with low yarn twists of F3 fabric despite its moderate fabric weight. Since low twisted yarns had bulkier structure resulting with less porous fabric structure as well as with low air permeability property.

\section{CONCLUSIONS}

The research presented in this paper assessed the effects of different constructional parameters on comfort properties of Turkish traditional Buldan woven fabrics. Buldan woven fabrics made of $100 \%$ cotton and cotton/Tencel blends were investigated in terms of thermal properties, water vapour and air permeability properties regarding to their fabric structural parameters such as fiber blend composition, yarn twist ratio, fabric unit weight and fabric thickness.

Experimental results showed that fabrics woven with cotton/Tencel blends indicated similar thermal resistivity values with those made from $100 \%$ cotton. Additionally, it was observed that fabric thickness was the most effective parameter on thermal resistivity where fabric weight followed it orderly. $100 \%$ cotton Buldan fabrics indicated the lowest thermal absorptivity with warmth feeling. Fabric weight was observed as a considerable parameter for the warmcool feeling of fabrics. It was observed that fabrics' cool feeling increased as the fabric thickness increased. Apart from early literature findings, it was also observed that fabrics which have the lowest twist ratio revealed the highest thermal resistivity resulting with the coolest feeling. It may be suggested to conduct further detailed studies about this contrasting result.

Experimental results showed that fabric thickness and fabric weight were the major parameters influencing the fabric air permeability. Moreover, yarn twist was the considerable factor among those with high fabric weight and thickness. It was observed that fabrics with the lowest weight and thickness indicated the highest air permeability while fabrics with the highest weight and thickness revealed similar air permeability. This result was attributed to high twisting ratios of the yarns from the fabric. Lowest air permeability was found among the fabrics made of yarns with the lowest twist. As a general evaluation, cotton/Tencel blended Buldan fabrics revealed similar thermal comfort properties with $100 \%$ cotton Buldan fabrics. However, the lowest thermal absorptivity was obtained from $100 \%$ cotton Buldan fabrics which are expected to provide warmth feeling.

\section{REFERENCES}

[1] Özer, L.M., A Regional woven fabric "buldan cloth", fabrics touching Anatolia, $7^{\text {th }}$ International Istanbul Textile Conference, 2016, 21-23 March, Istanbul-Turkey, 199-202

[2] Uğurlu, A., Uğurlu, S.S., Buldan cloth as the region's cultural identity, In: Buldan Symposium Proceedings Book, Pamukkale University, 2006, 23-24 November, Denizli, 275-280

[3] Utkun, E., Gündoğan, M.A., An application study aimed at improving the usage area of buldan weaving, In: Ejovoc (Electronic Journal of Vocational Colleges), 2014, 4, 4, 73-78

[4] Sezgin, Ş., Buldan weavings and Handworks, I. National Handcraft Symposium, Dokuz Eylül Universitesi Yayınları, İzmir, 1981, 321-333

[5] Erdoğan, Z., Buldan Dokumacıığı ve İlçede Üretilen Düz Dokumaların Bazı Özellikleri Üzerine Bir Araştırma, Ankara Üniversitesi Fen Bilimleri Enstitüsü, Ev Ekonomisi Anabilim Dalı Doktora Tezi, Ankara, 1996

[6] Öztürk, F., Çoruh, E., Buldan Dokumalarının Moda Endüstrisinde Kullanılabilirliğine Yönelik Bir Uygulama, In: Tekstil ve Mühendis Dergisi, 2013, 20, 91, 27-34

[7] Kahvecioğlu, H., An Investigation about some Mechanical Properties of Buldan Weavings, In: Buldan Symposium, Pamukkale, Denizli, 2006

[8] Atalayer, G., Twisted Cloth-Bükülü Bez (Bürümcük), In: Journal of Türkiyemiz, 1987, 53, 29-30 
[9] Özdemir, E.K., The effect of Industrialization in Textile Industry on Local Fabric Production: Denizli (Buldan-Tavas), In: Journal of Akdeniz Art, 2012, 4, 7, 137-140

[10] Öner, E., A Research about Comfort Properties of Woven Fabrics, Pamukkale University, Institute of Natural Applied Sciences, M.Sc. Thesis in Textile Engineering, 2008, 94

[11] Yoon, H.N., Buckley, A., Thermal Transport of Textiles for Comfort, In: Textile Research Journal,1984, 34, 3, 54-58

[12] Demir, Ö., The Effect to Fabric Comfort Properties used of Luxicool Fiber, Pamukkale University, Institute of Natural Applied Sciences, Textile Engineering, Msc Thesis, Denizli, 2016

[13] Havenith, G., The Interaction of Clothing and Thermoregulation, In: Exogenous Dermatology, 2002, 1, 5, 221-230

[14] Greyson, M., Encyclopedia of Composite Materials and Components, Wiley \& Songs, USA, 1983, 697

[15] Kawabata, S., Niwa, M., Sakaguchi, H., Applications to Product Design and Process Control, In: The Third Japan/Australia Joint Symposium on Objective Measurement, Osaka, Japan, 1985, 96-109

[16] Özdil, N., Marmaralı, A., Kretzschmar, S., Effect of Yarn Properties on Thermal Comfort of Knitted Fabrics, In: International Journal of Thermal Sciences, 2007, 46, 1318-1322

[17] Cimili, S., Nergis, B.U., Candan, C., Özdemir, M., A Comparative Study of Some Comfort-related Properties of Socks of Different Fiber Types, In: Textile Research Journal, 2009, 80, 10, 948-957

[18] Das, B., Das, A., Kothari, V. K., Fanguiero, R., Araujo, M., Moisture Transmission through Textiles Part I: Processes Involved In Moisture Transmission and The Factors At Play, In: AUTEX Research Journal, 2007, 7, 2, 100-110

[19] Das, B., Das, A., Kothari, V.K., Fanguiero, R., Araujo, M., Moisture Transmission through Textiles Part II: Evaluation Methods and Mathematical Modelling, In: AUTEX Research Journal, 2007, 7, 3, 194-216

[20] Turan, R.B., Okur, A., Air Permeability in Fabrics, In: Tekstil ve Mühendis, 2015, 72, 16-25

[21] Frydrych, I., Dziworska, G., Bilska, J., Comparative Analysis of the Thermal Insulation Properties of fabrics made of Neutral and Man-Made Cellulose Fibres, In: Fibres \& Textiles in Eastern Europe, 2002, 10, 4, 40-44

[22] Oğlakçıoglu, N., Marmaralı, A., Thermal Properties of some Knitted Structures, In: Fibres \& Textiles in Eastern Europe, 2007, 15, 5-6, 64-65

[23] Hes, L., Fundaments of Design of Fabrics and Garments with Demanded Thermophysiological Comfort, In: Textile Congress, Liberec, 2001, 94-95

[24] Uzun, M., An Investigation of Conventional and Compact Ring Spinning Techniques Effect on Tensile and Thermal Comfort Properties of Woven Fabrics, In: Marmara University Journal of Institute of Applied Natural Sciences, 2013, 25, 3, 91-99

[25] Mecheels, J.H., Umbach, K.H., The Psychometric Ranges of Clothing Systems, Clothing Comfort: Interactions of Thermal, Ventilation, Construction and Assessment Factors, Ann Arbor, MI: Ann Arbor Science Publishers 1977, 133-166

[26] Oğlakçığlu, N., Marmaralı, A., Effect of Regenerated Cellulose Fibers on the Thermal Comfort Properties of ompression Scoks, In: The Journal of Textiles and Engineer, 2008, 17, 77

[27] EN ISO 9237, Textiles, determination of the permeability of fabrics to air, International Organization for Standardization, Geneva, 1995

[28] Havenith, G., Interaction of clothing and thermoregulation, In: Exogenous Dermatology, 2002, 1, 5, 221-230

Authors:

\section{MINE AKGUN ${ }^{1}$, GIZEM KARAKAN GUNAYDIN², AYÇA GÜRARDA ${ }^{1}$ ERHAN KENAN ÇEVEN ${ }^{1}$}

${ }^{1}$ Bursa Uludag University, Faculty of Engineering, Textile Engineering Department, Bursa, Turkey email: akgunm@uludag.edu.tr, aycagur@uludag.edu.tr, rceven@uludag.edu.tr

2Pamukkale University, Buldan Vocational School, Fashion \& Design Programme, 20400, Buldan, Denizli, Turkey

Corresponding author:

GIZEM KARAKAN GÜNAYDIN

e-mail: ggunaydin@pau.edu.tr 